\title{
UMA PONTE ENTRE O REAL E O FANTÁSTICO: LEITURA DE UM CONTO DE MARIA ISABEL BARRENO
}

\author{
A BRIDGE BETWEEN THE REAL AND THE FANTASTIC: \\ READING OF A TALE BY MARIA ISABEL BARRENO
}

Marcelo Pacheco Soares ${ }^{1}$

\begin{abstract}
Resumo: Esse artigo propóe uma leitura ao conto "A ponte", da escritora portuguesa Maria Isabel Barreno, publicado em 1993. Para isso, fundamenta-se especialmente em teorias exclusivamente acerca do fantástico contemporâneo promovidas pelos críticos Ana Maria Barrenechea, Jean-Paul Sartre e Jaime Alazraki, segundo as quais a manifestaçăo desse gênero no século XX agencia uma compreensâo do mundo hodierno e de seus contextos sociais e políticos, tornando assim o fantástico, nâo obstante a sua narrativa ilógica ou sobrenatural, uma eficiente representaçâo mimética do real. Baseados nisso, verificamos nessa investigaçáo do conto de Barreno uma discussâo a respeito das insólitas decisóes tomadas pelos círculos de comando do mundo burocrático oficial do Estado, a revelarem o descompasso deste com a realidade dos seus cidadăos e da sociedade. Mais especificamente, deparamo-nos com uma análise a respeito da permanência (ou da sua impossibilidade), na contemporaneidade do Portugal dos anos 1990, das já passadas décadas da ditadura salazarista.
\end{abstract}

Palavras-chave: Fantástico do século XX. Conto português. Maria Isabel Barreno. Portugal contemporâneo.

Abstract: This article proposes a reading for the short story "A ponte", by the Portuguese writer Maria Isabel Barreno, published in 1993. For this, it is based on theories about the contemporary fantastic promoted by critics Ana Maria Barrenechea, Jean-Paul Sartre and Jaime Alazraki, according to whom the manifestation of this genre in the twentieth century promotes a reading of today's world and its social and political contexts, thus making the fantastic, despite its illogical or supernatural narrative, a mimesis of reality. Based on this, we find in this investigation of Barreno's tale a discussion about the unusual decisions promoted by the circles of command of the official bureaucratic world of the State, which reveals the mismatch of this State with the reality of its citizens and of society. More specifically we come to an analysis regarding the permanence, in the contemporaneity of Portugal of the 1990s, of the past decades of Salazar's dictatorship.

1 Professor do Instituto Federal de Educaçăo, Ciência e Tecnologia do Rio de Janeiro, Doutor (2012) e Mestre (2007) em Literatura Portuguesa pela UFRJ, com Pós-Doutorado (2016) pela UFF, pesquisador de contos fantásticos portugueses dos séculos XX e XXI.E-mail: marcelo.soares@ifrj.edu.br. 
Keywords: Fantastic 20th century. Portuguese tale. Maria Isabel Barreno. Contemporary Portugal.

Existirá a verdadeira realidade, a objetiva, aquela que se situa para além de qualquer interpretaçâo, de qualquer retoque da subjetividade humana?

Maria Isabel Barreno

Em suas "Teses sobre o conto", diz-nos o ensaísta argentino Ricardo Piglia que "um conto sempre conta duas histórias. [...] Um relato visível esconde um relato secreto, narrado de um modo elíptico e fragmentário" (PIGLIA, 2004, 89-90). Em "A ponte", conto da escritora portuguesa Maria Isabel Barreno, publicado originalmente em 1993, poderíamos dizer que o relato secreto da recente história portuguesa encontra-se camuflado pelo fabuloso relato visível de um espaço e um tempo genérico sem que ocorre, sobre uma ponte, um evento sobrenatural; ou, em outras palavras, nesse caso, o relato secreto de uma representaçăo mimética da realidade é encoberto pelo relato visível de uma narrativa fantástica. E eis que é a própria ponte do conto um entre-lugar desses dois relatos paralelos, elo que, ao fim da narrativa, une as suas duas margens.

\section{A LITERATURA FANTÁSTICA NO SÉCULO XX}

Em artigo de 1972 intitulado "Ensayo de una tipologia de la literatura fantástica", a crítica também argentina Ana Maria Barrenechea aponta que

los preocupados por problemas sociales, tan acuciantes en nuestra epoca, acusan de escapista a esta literatura y anuncian su desaparición por obsoleta, por no reflejar los problemas humanos más urgentes, por ser un arte burgués.A ellos habria que recordarles que los teóricos del marxismo no rechazaron por ese motivo a lo fantastico. [...] Esta posición o la de un Julio Cortazar que cifra la función revolucionaria del artista en revolucionar el ambito de las formas o la de un Umberto Eco que asigna ese poder revolucionario a la destrucción y creación de nuevos lenguajes, abren tambien al genero otras posibilidades bajo el signo de lo social, siempre que lo fantastico sea una puesta en cuestión de un orden viejo que debe cambiar urgentemente (BARRENECHEA, 1972, p. 402-3).

Nesse seu trabalho, Barrenechea refere-se especificamente a umfantásticoque passou a ser produzido a partirdo século XX.Sua discussăo, desse modo, ao contestar o desaparecimento da literatura fantástica por obsolência, estabelece um contraponto à afamada pesquisa Introduçâo à Literatura Fantástica, publicada pelo filósofo Tzvetan Todorov quatro anos antes, segundo a qual, defendera ele, o fantástico“teve uma vida relativamente breve [já que] os contos de Maupassant representam os últimos exemplos esteticamente satisfatórios do gênero" (TODOROV, 2004, 174-5), segundo seus critérios,assim fortemente limitando ao século XIX as suas efetivas manifestaçóes possíveis. Barrenechea, renunciando a essa percepçăo, aponta entăo que a produçâo do gênero (ou desse modo literário - oposiçâo que năo será mister desenvolvermos aqui) persiste no século seguinte, ainda que, em muitas obras (e, claro está, náo exatamente 
em todas, porque, evidentemente, nada impediu que narrativas que emulassem a poética do fantástico oitocentista seguissem sendo em concomitância produzidas mesmo até os nossos dias), apresente-se comportamento distinto em algunsaspectos.

Dentre esses traços diferentes, destaca-se a falta de necessidade da ocorrência do que Todorov chamara hesitaçâo, considerada por ele, dentre outros traços que o teórico elenca, um componente fundamental da construçăo do fantástico: "O fantástico é a hesitaçăo experimentada por um ser que só conhece as leis naturais, face a um acontecimento aparentemente sobrenatural" (TODOROV, 2004, p. 31) - conforme estabeleceria o pesquisador franco-búlgaro. Ora, Barrenechea, buscando ampliar o corpus que Todorov efetivamente restringira aos 1800, recusa a dúvida dos personagens ou dos leitores como traço fundamental à construçấo de textos dessa natureza precisamente por observar narrativas do século XX que, ainda que náo estabelecessem uma representaçăo tecnicamente realista do mundo, encontravam-se nitidamente marcadas por uma falta de surpresa diante do elemento sobrenatural - fenômeno, aliás, que o existencialista francês Jean-Paul Sartre, na década de 1940, em artigo sobre o romance Aminadab de Maurice Blanchot, também já percebera, ao identificar no que chama de fantástico contemporâneo (nomeadamente as obras pós-kafkianas) uma narrativa onde, diante do irreal, personagem algum "jamais se espanta: [...] como se a sucessâo dos acontecimentos aos quais assiste lhe parecesse perfeitamente natural" (SARTRE, 2005, p. 144). E é verdade ainda que, embora priorize a literatura fantástica oitocentista como corpus, no fim de sua obra, precisamente nas páginas finais, Todorov reconheça em Kafka o surgimento de uma nova literatura (a qual ele năo classifica necessariamente como novo fantástico, mesmo admitindo a sua sobrenaturalidade), produto de uma sociedade em que "năo se pode mais acreditar numa realidade imutável, externa, nem em uma literatura que năo fosse senâo a transcriçáo desta realidade" (TODOROV, 2004, p. 176) - uma realidade, pois, in-crível - de modo que realiza sua leitura de A metamorfose, do autor tcheco, apontando que essa narrativa "abandona aquilo que tínhamos designado como a segunda condiçâo do fantástico: a hesitaçâo representada no interior do texto, e que caracteriza especialmente os exemplos do século XIX" (TODOROV, 2004, p. 181), concluindo por fim que, "aqui, é a própria personagem principal que se torna 'fantástica'" (TOROROV, 2004, p. 182).

Assim, a fim de que năo se descaracterizassem tais narrativas como fantásticas conforme poderia se inferir da leitura de Todorov, cuja teoria enfim é confessadamente pertinente a uma forma de narrar da poética do fantástico do século XIX - a pesquisadora argentina, nesse posto de particularidade fulcral do gênero, substitui a hesitaçâo todoroviana por outro conceito, o da problematizaçâo:

Asi la literatura fantástica quedaría definida como la que presenta en forma de problema hechos a-normales, a-naturales o irreales.Pertenecen a ella las obras que ponen el centro de interés en la violación del orden terreno, natural o lógico, y por lo tanto en la confrontación de uno y outro orden dentro del texto, en forma explícita o implícita (BARRENECHEA, 1972, p. 393).

A partir desseconceito de que o fantástico possuiria a funçăo de problematizar o real, a ensaístaacrescenta ainda que, em certas obrasproduzidas no século XX, seria possívelreconhecer a constituiçấo da realidade daquilo que se crê irreal e a denúncia da irrealidade daquilo que acreditamos real - evidenciando, portanto, nesse fantástico 
dos novecentos, náo uma simples ruptura, mas uma contaminaçăo do real pelo irreal, um amálgama (mesmo que a partir de algum nível de confrontación, sem o qual, afinal, năo se configura o gênero) entre esses mundos, como, ademais, havia já nesse caso reconhecido Todorov: "Eis em resumo a diferença entre o conto fantástico clássico e as narrativas de Kafka: o que era uma exceçăo no primeiro mundo torna-se aqui uma regra" (TODOROV, 2004, p. 182). Mas nos parece que o mais importante na teoria de Barrenechea, aquilo que se revela essencial aos nossos desígnios no momento, encontra-se nessa aproximaçáo que a autora estabelece entre a esfera social e a literatura fantástica.

Ora, Todorov já observara no fantástico do século XIX alguma funçâo social - "uma lista de temas proibidos, estabelecida por alguma censura" (TODOROV, 2004, p. 167) era abordada por essa poética de modo indireto, de forma que "a funçăo do sobrenatural é subtrair o texto à açăo da lei e com isto mesmo transgredi-la" (TODOROV, 2004, p. 168), conclui ele - funçâo essa que, todavia, estaria no século XX, ainda de acordo com o autor, superada pelo advento da psicanálise e por sua consolidaçăo no século seguinte. Com isso, porém, năo concordamos: ocorre que sempre há questóes a serem transgredidas e, ainda que a psicanálise houvesse suplantado algumas (e năo o fez de todo, porque sempre sobram grupos mais conservadores que a rechaçam), haverá outros temas, de esferas distintas (como as politicossociais, por exemplo) que careçam desse modo indireto do fantástico para serem abordados e transgredidos, especialmente em um contexto como o do século XX, em que os mais variados governos ditatoriais estabeleceram-se pelo mundo. Daí que nos seduza a percepçăo de Barrenechea quanto a relaçăo entre a realidade da sociedade (com suas demandas a serem examinadas e debatidas) e a narrativa insólita novecentista, o que vincula sobremaneira o fantástico a um real mimético de que a princípio estaria apartado e o qual, por uma estratégia indubitavelmente distinta do realismo (e quiçá mais eficiente), é representado por essas narrativas que, năo obstante sua sobrenaturalidade ou ilogicidade, de modo algum delese afastam, como se poderia pensar acerca do gênero em uma leitura sua mais imediata (e, nesse caso, igualmente mais superficial).

Convidando ao colóquio, uma vez mais, um crítico argentino, encontramo-nos com Jaime Alazraki, que propóe o termo neofantástico ao investigar sobretudo as obras de seus compatrícios Julio Cortázar e Jorge Luis Borges (mas também a de outros, como Kafka), desenvolvendo, a partir da década de 1980, conceitos ainda mais similares aos das visóes de Sartre e Barrenechea ao cunhar essa nomenclatura para dar conta de manifestaçôes do gêneroem funçáo das características distintivaspertinentes à sua produçăo no século XX:

En contraste con la narración fantástica del siglo XIX en que el texto se mueve de lo familiar y natural hacia lo no familiar y sobrenatural, como un viaje a través de un territorio conocido que gradualmente conduce a un territorio desconocido y espantoso, el escritor de lo neofantástico otorga igual validez y verosimilitud a los dos órdenes, y sin ninguna dificultad se mueve con igual libertad y sosiego en ambos (ALAZRAKI, 1994, p. 69).

Para Alazraki, "si lo fantástico asume la solidez del mundo real - aunque para 'poder mejor devastarlo', como decía Callois -, lo neofantástico asume el mundo real como una máscara, como un tapujo que oculta una segunda realidad que es el verdadero destinatario de la narración fantástica" (ALAZRAKI, 2000, p. 276).Essa visâo, algo platônica algo marxista, de que o mundo real seria como uma máscara que oculta uma segunda 
realidade comporta-se de modo, se nâo semelhante,nitidamente complementar à ideia de Barrenechea de que, no século XX, o fantástico apresenta a funçăo de problematizar o real, para entâo, como reconhece agora Alazraki, mais bem revelá-lo e, assim, desmascará-lo. Pode-se acrescentar que, nessa mesma esteira argumentativa, o escritor italiano Italo Calvino, em 1970, teceu as seguintes consideraçōes ao jornal francês Le Monde, em resposta à pesquisa quanto à recepçâo crítica da teoriade Todorov:

Le fantastique du XIX siècle, produit raffiné de l'esprit romantique, est entre tout de suite dans la littérature populaire (Poe écrivait pour les journaux).Au XXe siècle, c'est un emploi intellectual (et non plus émotionnel) du fantastique qui s'impose. Le fantastique y apparaît comme jeu, ironie, clin d'œil, mais aussi comme méditation sur les cauchemars ou les désirs cachés de l'homme contemporain (CALVINO, 1993, p. 56).

Pois Sartre, percebendo na contemporaneidade precisamente a existência de um fantástico humano, já afirmara no seu citado artigo: "Para o homem contemporâneo, o fantástico tornou-se apenas uma maneira entre cem de fazer refletir sua própria imagem" (SARTRE, 2005, p. 139). Mais enfaticamente, diríamos que esse fantástico reflete a respeito da própria imagem do homem, como, é preciso admitir, fazia desde a sua gênese; questōes relativas a aspectos psicanalíticos, todavia, uma vez que, reiteremos, teriam encontrado segundo mesmo Todorov caminhos de resoluçáo em um mundo pós-Freud, abrem lugar para tópicos que configuram uma nova camada de desconhecimento sobre o ser humano, o que levara Sartre a entender que já nâo há senão um único objeto fantástico: o homem: "Nâo o homem das religiôes e do espiritualismo, engajado no mundo apenas pela metade, mas o homem-dado, o homem-natureza, o homem-sociedade" (SARTRE, 2005, p. 138) - ele assevera.

O Fantástico que surge a partir do advento do século XX representa, entăo, uma larga porta de entrada à discussăo da condiçăo de existência do homem moderno, burocratizado e maquinizado em uma realidade filha das revoluçóes (a Francesa, as Industriais, as econômicas) cujo propagandeado sucesso (ao menos um sucesso absoluto) é uma forjada utopia. A seduçăo pelo enigma que o texto insólito empreende será, dessa maneira, uma forma de atrair o leitor e fazê-lo voltar o seu olhar para questóes que o seu cotidiano absorveu, bloqueando a atençấo sobre elas, as quais talvez nem sempre encontrem no texto mais propriamente realístico (chamemo-lo assim por agora, para economia de meios) um instrumento capaz de provocar com intensidade a meditaçăo sobre si mesmo. A literatura fantástica do último século, engajada nessas discussôes, será, por conseguinte, um pré-texto; e o fundamental a seu respeito estará, via de regra, em sua leitura segunda (como a narrativa oculta a que se referiria Piglia, se nos for permitida uma livre associaçâo das duas ideias). O fantástico genuinamente novecentista é aquele que problematiza o real, aquele que desmascara uma segunda realidade, em suma, aquela que denuncia a realidade do que se crê irreal e a irrealidade do que acreditamos real e, ainda, medita sobre os pesadelos ou os desejos ocultos do homem contemporâneo, ou seja: discute quetôes que concernem às necessidades e aos problemas desse que Sartre chamou de homem-sociedade. Mais do que o fato de năo necessariamente causar horror ou provocar a hesitaçăo, esse aspecto, por aproximar essas narrativas do século XX de uma estrutura algo alegórica, talvez seja o que mais afasta Todorov de suas leituras e do reconhecimento dos seus estatutos de textos fantásticos, dado que o pesquisador enumera em sua obra uma série de narrativas em que o fantástico "é morto pela alegoria" (TODOROV, 2004, p. 75). Segundo ele, "se o que 
lemos descreve um acontecimento sobrenatural, e que exige no entanto que as palavras sejam tomadas năo no sentido literal mas em um outro sentido que năo remeta a nada de sobrenatural, náo há mais lugar para o fantástico" (TODOROV, 2004, p. 71). Ora, nâo podemos, contudo, com isso concordar. Se, como nos aponta ainda mais um teórico de origem argentina, Alberto Manguel, em assertiva sobre os contos kafkianos que náo deixam também de referenciar a literatura em geral, "cada texto pode ser lido como uma alegoria" (MANGUEL, 2004, p. 50), ou, segundo nos lembra por sua vez o professor português Carlos Ceia, "a chamada crítica arquetípica defende, como o faz Northrop Frye em The anatomy of Cristicism (1957), que toda a análise literária deve ser alegórica" (CEIA, 1998, p. 24-5), a proposta de Todorov - mesmo baseada no princípio de que "năo se pode falar de alegoria a menos que dela se encontrem indicaçôes explícitas no interior do texto" (TODOROV, 2004, p. 81) - quiçá legasse a toda narrativa o potencial para năo ser fantástica, dependendo da pré-disposiçăo de atuaçăo por parte do leitor.

\section{"A PONTE" DE MARIA ISABEL BARRENO}

Toda essa discussăo acerca da relatividade do real năo estaria de modo algum distantedas concepçóes literárias da escritora portuguesa Maria Isabel Barreno, náo apenas por ser ela autora de novelas e, especialmente, contos que comumente transitam pelo fantástico, pelo insólito, pelo sobrenatural, pelo ilógico ou pelo absurdo, mas também porque Barreno mesma, em artigo sobre o seu próprio fazer poético, levanta questóes semelhantes às aqui discutidas ao tratarda relatividade da realidade, ainda que o faça em debate sobre um assunto que apenas tangenciaria o que desenvolvemos até agora, tratandodo imaginário das narrativas de um modo geral e náo necessariamente discursando sobre um gênero literário específico:

O que vemos e o que vivemos náo é o real. É o nosso real, determinado pelo nosso campo subjetivo particular, determinado pelos dados básicos de nossa personalidade e por todo o condicionamento a que nos expôs a educaçăo, a socializaçăo, todas as circunstâncias da vida que vivemos na sociedade em que nos criamos.

Existirá a verdadeira realidade, a objetiva, aquela que se situa para além de qualquer interpretaçăo, de qualquer retoque da subjetividade humana (BARRENO, 2001b, 275)?

É sob essa ótica - de uma realidade que, se é antes subjetiva do que objetiva, é tambémmais relativa do que absoluta - que, com a expectativa de encontrar no fantástico, mais do que uma representaçăo do real (verdadeiro), a representaçáo de um real (possível), voltamos o nosso olhar para a curta narrativa de Barreno intitulada "A ponte" e cuja primeira ediçăo em livro encontra-se na coletânea Os sensos incomuns, volume laureado em 1993 com o Grande Prêmio do Conto Camilo Castelo Branco/APE, em uma das primeiras ediçôes dessa hoje importante distinçăo, e ainda com o Prêmio P.E.N. Clube no ano seguinte. Ressaltemos que a autora publicou um romance, alguns anos mais tarde, com o mesmo título, primeiramente sob o pessoano pseudônimo de Ricardo Caeiro e posteriormente em nova ediçâo que assinava efetivamente com o seu nome, mas a trama desse seu trabalho, apesar da coincidência batismal, náo se relaciona diretamente com o do conto em análise, embora outras pontes possam ser lançadas entre eles, como ainda poderemos aludir. 
O enredo do conto gira em torno de uma pequena ponte cuja irrealista (para usar as palavras da próprianarrativa) placa que indica a velocidade máxima permitida para sua travessia, jamais trocada em muitas décadas (ali estaria desde 1933, redondos sessenta anos antes da publicaçăo do texto, opçáo de data que, como veremos, năo deve ser aleatória), aponta para uma defasada e infactível velocidade de dez quilômetros por hora - "restos do tempo em que os estralejantes automóveis de manivela assustavam as povoaçôes ao ponto de lhes dar a certeza do fim do mundo" (BARRENO, 2001a, 83).

Nâo se trata, destaque-se, de uma ponte em lugar ermo, em um espaço mais apartado da lógica das grandes cidades em que a vagarosidade poderia justificar-se; antes, ela é identificadacomo uma via de passagem importante, em local com trânsito mais intenso, como a narrativa năo deixa de enfatizar:

\begin{abstract}
Ali, no início de ambos ossentidos da ponte, que tinha muito trânsito, nada podia passar despercebido. Nem o impraticável limite fixado, que fazia os automobilistas rir, concluir rapidamente pela estupidez das autoridades e determinar a sua própria versáo da velocidade possível desejável. Com essas versóes eram tăo variadas quanto a personalidade dos condutores, indo desde os razoáveis cinquenta quilómetros até aos psicóticos cem quilómetros por hora, passando por muitas outras velocidades e modos de conduzir saudáveis e neuróticos, os desastres ocorriam diariamente. Tăo diariamente que a ponte deixou de ser notícia. Os repórteres na televisâo limitavam-se a dizer mais um morto na ponte, ou mais dois, ou mais cinco. Sem detalhes, passando adiante, quase encolhendo os ombros (BARRENO, 2001a, 83-4).
\end{abstract}

O absurdo da lei retira-lhe, portanto, uma concreta autoridade e, na sua ausência prática, gera uma organizaçăo social que poderia mesmo estar baseada (ao menos nesse entre-lugar que é a ponte) em um conceito de anarquia que leva cada automobilista efetivamente a automover-se, ou seja, autogestar-se no que diz respeito às leis de trânsito. As subjetividades humanas, no entanto, têm por consequência a ausência de um senso acerca do tema, levando antes a um conjunto de sensos incomuns, como apontava o título do livro que abriga esse conto, ou seja,gerando uma variedade de velocidades que săo praticadas tăo diversamente quanto existem as individualidades de cada um dos condutores - razoáveis ou psicóticas, saudáveis ou neuróticas.

É após um jornalista produzir matéria mais apurada sobre o caso que alguma reaçăo é percebida entre as autoridades públicas, no entanto, sob uma áurea que de modo algum seria avessa ao universo kafkiano que rege o fantástico do século XX, a pseudo-vontade dos governantes para resolver a matéria - "As autoridades abriram entâo um olho. Só um, năo os dois. Uma pálpebra preguiçosamente erguida, um olhar mole." (BARRENO, 2001a, 84), aponta causticamente a narraçâo - esbarra em questiúnculas políticas e na lentidăo dos círculos burocráticos do Estado.Nas conjecturas sobre que novo limite impor, os governantes pensam em no máximo dobrar o limite, pois "saltos bruscos de mais de cem por cento năo nos parecem aconselháveis" (BARRENO, 2001a, 84), refletem eles, certamente porque o tamanho exagerado da transposiçăo potencializaria proporcionalmente o aspecto ridículo da lei anterior e exporia a própria defasagem, o próprio erro de cálculo de suas presentes administraçōes.

Mas vinte quilômetros por hora segue sendo uma soluçăo também comicamente infactível e ainda em absoluto descompasso com a realidade, com o progresso e o desenvolvimento tecnológico da sociedade, de modo que, para que seja tomada uma decisăo sobre o tema, decide-se por um estudo a ser feito por uma comissâo a ser 
nomeada. Trata-sedas típicas satisfaçōes do Estado diante de circunstâncias sobre as quais năo se pretende ou năo se consegue tomar providências, para que se ganhe tempo esperando-se que o assunto arrefeça ou talvez se solucione por si mesmo, o que a narrativa, aliás, explicita ao expor a leitura acerca do comportamento do governo efetivada pelas chamadas, novamente com certa dose de ironia, elites informadas de iniciados nos circuitos do poder: "as autoridades nunca tinham feito tençōes de mudar o sinal, até ao final dos trabalhos da tal comissăo que estava a receber chorudos honorários, e a manobra da medida prévia experimental fora pura demagogia, poeira nos olhos dos crentes" (BARRENO, 2001a, 86), conforme conjecturam esses ditos entendidos de política. A indignaçâo da populaçăo, especialmente dos familiares de mortos e de feridos em acidentes na ponte - fomentados pelo discurso da imprensa queentâo, já com algum lucro trazido pelos "cabeçalhos muito vendáveis nos jornais" (BARRENO, 2001a, 85), adota com mais veemência o caso - acaba conduzindo o primeiro-ministro a decidir por mudar a placa antes dos resultados da comissăo formada, no entanto, promessa vazia, "para evitar que alguém fosse desautorizado, ou que alguém se sentisse desautorizado, ou que alguém pensasse que poderia desautorizar alguém ou, enfim, para que nenhum jornalista atrevido pretendesse encontrar no caso qualquer sintoma de vício ou corrupçăo" (BARRENO, 2001a, 85), a placa, no fim das contas, năo é trocada.

A vagarosidade, portanto, da defasada placa - limitando a velocidade máxima a um nível baixíssimo, impraticável e caricato - configura-se, antes, em uma expressiva metonímia metafórica do próprio Estado, espécie de alegoria de sua lentidāo para atender os anseios da sociedade, resolver os seus problemas e gerir o seu funcionamento. Daí o inventário de impedimentos, próprios de uma pouco competente administraçáo pública, que as autoridades usam para justificar a falta de soluçâo e os atrasos da comissâo formada: vagas circunstâncias burocráticas, falhas de comunicaçâo ainda nâo corrigidas, excessos de procedimentos necessários para o cumprimento de tăo simples empreitada como o levantamento de "orçamento de três empresas do ramo para a execuçăo de novos sinais" (BARRENO, 2001a, 86).

Ora, esse Estado entăo produz e mantém leis que apenas existem em uma realidade teórica e que lhe é intrínseca, pseudorrealidade essa que é incompatível com a realidade sensível dos cidadâos. Assim é que a impossibilidade de o cidadăo desse espaço real transitar no mundo pensado pelos membros daquilo que a própria narrativa chama de circuitos do poder - espaço, a propósito, novamente quase tăo fechado quanto os apresentados por Kafka em suas narrativas do início do século - acaba tendo por consequência a cena do conto em que se alcança o seu mais manifesto nível de fantasticidade:

Houve entăo um homem que resolveu segui-lo, cumpri-lo à risca: a ele, sinal. Abrandou na entrada da ponte para dez quilómetros horários, e arrastou-se como pôde, em primeira, fazendo o possível por năo deixar o carro soluçar, num jogo delicado de embraiagem e acelerador, ponte fora.

Juntou-se gente para ver aquele propósito despropositado, como também sempre acontece. Uns aplaudiam, outros vaiavam, outros riam. Vê lá năo adormeças ao volante, diziam. Queres que vá telefonar à tua mulher par ela te trazer o jantar?, diziam. Depois cessaram os risos, as vaias, as chalaças. A meio da ponte o homem desapareceu (BARRENO, 2001a, 86-7).

Ou seja, ainda que pudesse parecer paradoxal (conclusâo a que a introduçâo teórica 
que aqui desenvolvemos em verdade, ou assim esperamos, nâo permite que se chegue), reside precisamente nessa cena do conto - em que sobressai o efetivo elemento sobrenatural - o maior potencial mimético da realidade empírica que se encontra no decorrer da narrativa, já que é através dessa passagem que se concretiza a sua denúncia (problematizaçâo do real, desmascaramento de uma segunda realidade) de uma sociedade cujas regras săo pensadas e mantidas em desacerto com as necessidades dos seus cidadăos, os quais năo podem haver nesse espaço hipotético que o Estado tenta fazer existir ou crê que exista. A estratégia empreendida é curiosa porque toda a açăo descrita até entăo, ainda que isenta do sobrenatural, descrevia uma situaçăo tăo insólita e tăo absurda (a manutençấo da placa irrealista, as formas de açăo das autoridades...) que estávamos, de fato, desde o início diante da própria irrealidade real a que se referira Barrenechea, enquanto o fantástico em si surge mais explicitamente na narrativa, portanto, pelo contrário, no contexto da realidade do que se creria irreal, năo sendo pertinente, por isso mesmo, que já năo se considerasse que a narrativa transitava pelas vias do fantástico antes do evento decisivo, ainda que fosse um fantástico que nos seja tăo cotidiano.

\section{PORTUGAL E A METAMORFOSE DE UMA PONTE}

Mas essa é apenas a camada mais universal que o conto acolhe, a sua possibilidade de representar o funcionamento das sociedades modernas em geral, com suas organizaçóes políticas potencialmente falhas. A despeito de a narrativa năo precisar o espaço geográfico em que se desenvolve, o seu lugar de produçáo (a origem de sua autora) inevitavelmente nos deve encaminhar também a uma leitura de "A ponte" que considere que os eventos do conto ocorreriam emum contexto mais especificamente português. Dessa forma, năo é um dado que possa de modo algum nos passar despercebido a informaçăo de que a placa havia sido posta naquele lugar em 1933, uma vez que esse é um ano-chave na relativamente recente história do país, por conta da promulgaçấo da Constituiçấo que marca o início da ditadura de Antonio de Oliveira Salazar (que seria entăo o primeiro-ministro do país pelos próximos 35 anos) e é o marco inaugural do Estado Novo, o qual perduraria até 1974, quando a Revoluçăo dos Cravos estabeleceria o seu término.

Portanto, os exacerbados limites à velocidade máxima da placa em questăo poderiam facilmente associar-se também, por exemplo, a um período de forte censura que se observou durante o salazarismo, que vigiava e punia os adversários através da sua polícia de repressáo política, a PIDE, em um contexto em que apenas o partido da situaçăo era legalizado, consequentemente, restringindo com rigor absoluto (limitando, portanto, a níveis mínimos), a partir desse controle social, as atuaçóes de qualquer oposiçăo. Ao mesmo tempo, as mortes na ponte e o desaparecimento final de um condutor seriam episódios que remeteriam às vítimas dessa mesma repressăo. E de igual modo, finalmente, as referências ao comportamento dos membros da administraçăo pública no conto (incluindo aí justamente um primeiro-ministro, a funçăo máxima do Poder Executivo português que fora ocupadapor Salazar durante quase todo o período dessa ditadura), tal qual o aparelhamento dos espaços burocráticos que a narrativa denuncia, poderiam relacionar-se com essa organizaçâo política distinguida por um Estado excessivamente forte e intervencionista que se opunha ao liberalismo econômico da Velha República a qual viera a substituir, vendendo-se como soluçăo para os fracassos sociais e econômicos desta. 
Mas podemos ir além disso, já que, tomando(sob estratégia semelhante à questâo espacial) o tempo do conto como contemporâneo à sua publicaçăo - e năo há na narrativa algo que deponha contra isso, tampouco que indique o contrário - o que teríamos em "A ponte" seria năo uma representaçăo do contexto temporal do Estado Novo, mas antes uma indicaçâo dos resquícios de sua permanência na sociedade portuguesa da contemporaneidade do conto, já que a placa, surgida no ano da ascensâo do regime salazarista,persistia em seu lugar mesmo após quase vinte anos do fim do período. Desse modo, pareceríamos estar diante de consequências do salazarismoem Portugal que resistiriam ao fenecimento. Por outro lado, talvez năo seja ainda essa a conclusấo mais plausível. O desaparecimento do automóvel com seu motorista em seu propósito absurdo de obedecer à placa (ou seja, na tentativa vă de seguir antigos ditamesdo Estado Novo na sociedade portuguesa da atualidade) indica a impossibilidade de retorno das ideologias que sustentaram aquele regime, ao menos nesse princípio dos anos 1990 (os nossos dias atuais, em que se testemunham promoçôes de ideias fascistas pelo mundo ocidental tanto na Europa quanto na América, cremos, lamentavelmente já nâo afiançam isso), uma vez que segui-las o faz desaparecer da realidade, talvez para surgir em outra dimensăo, como algumas testemunhas supóem, em outro tempo da ponte.

Nesse sentido, aliás, é curioso notar que a ponte do conto deveras se aproximaria de uma referência concreta,uma famosa construçâo portuguesa que, atravessando sobre o rio Tejo, liga as cidades de Lisboa e Almada. Construída justamente no tempo do Estado Novo e inaugurada em 1966 após quatro anos de trabalhos, a mais emblemática obra edificada no regime e divulgada na época como a maior ponte da Europa recebeu em sua inauguraçăo (transmitida ao vivo pela televisăo) o nome de Ponte Salazar, mas meses após a Revoluçăo dos Cravos foi rebatizada de Ponte 25 de Abril, alcunha oficial que ostenta até os dias atuais. Năo estamos dizendo, é claro, que o cenário em que se desenvolve o conto seja efetivamente o dessa ponte lisboeta. Esse seria o caso, na verdade, do romance que a autora lança em 1998, que antes citamos, também intitulado $A$ ponte, o qual, a partir da morte de um homem por policiais em uma manifestaçăo exatamente na Ponte 25 de Abril, propóem-se a cotejar as geraçóes portuguesas de 1960 e de 1990, representadas em um pequeno grupo de amigos e familiares. Em relaçáo ao conto, todavia, essa referência será indireta e a ela chegamos por uma leitura mais sutil, como se outra vez mais estivéssemos diante na narrativa de uma transformaçâo fantástica do concreto referente mimético que seria a ponte real.

Mas o fato de o posterior romance ter por mote também fazer essa leitura acerca das relaçôes entre os contextos dos anos finais da ditadura portuguesa e do fim do século XX reforça que já a possamos identificar nesse conto homônimo seu. Desse modo,parece-noscrível concluir que o desaparecimento do automóvel no conto de Barreno, sua entrada "noutro mundo, noutra dimensăo, [...] na quinta dimensăo" (BARRENO, 2001a, 87), indicaçăo espaço-temporal a propósito dois graus distantes da nossa realidade tridimensional, indicaria que as formas absurdas de funcionamento do Estado Novo no tempo da Ponte Salazar estejam apartadas da sociedade contemporânea o suficiente para que năo mais sejam capazes de existir na conjuntura da Ponte 25 de Abril. Assim, jogando ainda com nomenclaturas da esfera da física, observaríamos por fim que, em um conto cuja palavra inaugural é velocidade e a terminal é tempo, grandezas físicas relacionáveis, o objetivo da narrativa seria justamente calcular e expor a grande distância que há entre essas duas pontes. 


\section{CONCLUSÃO}

Por conseguinte, a própria ponte da narrativa, dizíamos no início,será o entre-lugar que une as duas margens da obra, onde estăo os relatos visível e secreto que Piglia identificara como as faces presentes em todo conto. Aqui, através dessa ponte, ligam- se nâo apenas o fantástico e uma realidade empírica, nem mesmo somente a realidade do irreal e a irrealidade do real de que nos fala Barrenechea ou a primeira realidade aparente e a segunda realidade oculta de que trata Alazraki, mas também, em específico, o Portugal do Estado Novo e o Portugal dos anos 1990. Mais do que isso, essa ponte ficcional é instrumento para a constataçâo de que a absurda realidade do salazarismo - com que Barreno já se debatia desde que, comMaria Teresa Horta e Maria Velho da Costa, produziu as feministas Novas cartas portuguesas, que, publicadas em 1972 por Natália Correia e censuradas pelo regime, levaram-nas a sofrer acusaçóes, perseguiçóes e violências de várias ordens por parte da ditadura patriarcal que as conduziu a julgamento, processo de que somente foram absolvidas após a Revoluçáo dos Cravos - tal realidade absurda, dizíamos, năo pode continuar a ter parte numa sociedade que ainda lhe herdava, segundo denuncia o próprio texto, um velho e grande Estado que, ignorando as necessidades das comunidades, governa-as sem assumir efetiva responsabilidade sobre elas. Embora o conto năo desenhe um Estado deliberadamente violento como o do tempo salazarista, porque essa sua faceta de fato havia arrefecido com o fim do regime totalitarista, nâo deixa de constatá-lo como, apesar de custoso (lembremos a comissấo e seus chorudos honorários), inoperante e omisso. Curiosamente, reside nessa omissăo, e nâo numa redençấo, o efeito que o trágico evento fantástico promove nas autoridades, porque apóso desaparecimento inexplicável do automóvel é que a placa será sigilosa e repentinamente trocada, como em um lavar-das-máos dos governantes, que trata logo de buscar maneira de năo tomar parte no acontecimento:

Os sinais foram entâo mudados, rapidamente. Para cinquenta à hora, porque era a velocidade mínima praticada pelos desobedientes, segundo se apurou num inquérito de rua. Nâo houve mais resistências surdas, oposiçōes misteriosas, entraves burocráticos e funcionários de finanças; nem se ouviu falar mais na comissăo.Tudo indicava que mais ninguém queria responsabilidades naquilo, as mais elementares e necessárias decisóes ficaram trancadamente anónimas. Até a mudança dos sinais foi feita de noite. E os desastres por excesso de velocidade acabaram (BARRENO, 2001a, 88).

Ainda assim, como resultado metalinguístico do que aqui tratamos, o que temos é o evento fantástico influenciando a realidade, denunciando suas deficiências e mesmo corrigindo-as.E a estratégia para que os erros nâo sejam cometidos novamente reside na manutençăo de sua memória. Daí a funçăo do personagem que surge no fim do conto, "um homem que costumava enrolar cigarros, vagarosamente, e fumá-los, junto à entrada da ponte" (BARRENO, 2001a, 88). Apesar do fim dos acidentes a partir do aumento do limite da velocidade, ele "permaneceu junto à ponte e transformou-se num cronista desses desastres idos, um cicerone do tempo" (BARRENO, 2001a, 88) - e novamente o Estado Novo e a ditadura salazarista estăo referidos por tais desastres felizmente idos.

Com esse objetivo é que, também como cronista desses tempos, que năo podem mesmo ser esquecidos precisamente para que năo retornem, apresenta-se Maria Isabel Barreno na escrita desse fantástico conto fantástico. 


\section{REFERÊNCIAS}

ALAZRAKI, Jaime. Hacia Cortázar: aproximaciones a su obra. Barcelona: Antrophos, 1994

¿Qué es lo neofantástico? In: ROAS, David. Teorías de lo fantástico. Madrid: Arco/ Libros, 2000, p. 265-82.

BARRENECHEA, Ana Maria. Ensayo de una tipologia de la literatura fantástica. In: Revista Iberoamericana. Pittsburgh: University of Pittsburgh, ํㅡ 80, julho-setembro, 1972, p. 391-403.

BARRENO, Maria Isabel. A ponte. Lisboa: Dom Quixote, 2004.

A ponte. In: .Os sensos incomuns. Lisboa: APE, 2001a.

Os territórios imaginários da escrita. In: Revista Scripta. Belo Horizonte, v. 4, n. 8, p. 275-286, 1o sem. 2001b.

CALVINO, Italo. Définitions de territoires: le fantastique. In: . Le machine littérature. Paris: Seuil, 1993, p. 55-6.

CEIA, Carlos. Sobre o conceito de alegoria. In: Revista Matraga. Rio de Janeiro, n. 10, p. 19-26, outubro de 1998.

MANGUEL, Alberto. Umahistória da leitura. Traduçăo: Pedro Maia Soares. Saao Paulo: Companhia das Letras, 2004.

PIGLIA, Ricardo. Teses sobre o conto. In: Formas breves. Traduçâo: José Marcos Marinani Macedo. Sâo Paulo: Companhia das Letras, 2004, p. 87-94.

RODRIGUES, Luís Ferreira. A ponte inevitável - A história da Ponte 25 de Abril. Lisboa: Guerra \& Paz, 2016.

SARTRE, Jean-Paul. Aminadab, ou o fantástico considerado como uma linguagem. In: Situaçôes I - críticas literárias. Traduçăo: Cristina Prado. Săo Paulo: Casac Naify, 2005, p. 133-49.

TODOROV, Tzvetan. Introduçâo à Literatura Fantástica.Traduçăo: Maria Clara Correa Castello. Săo Paulo: Perspectiva, 2004.

Submetido em 20 de março de 2018 Aceito em 17 de maio de 2018 